\title{
Inadequacy of gestational weight gain during high-risk pregnancies is not associated with household food insecurity
}

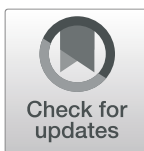

Aléxia Vieira de Abreu Rodrigues ${ }^{1 *}$, Ana Lúcia Pires Augusto ${ }^{2}$ and Rosana Salles-Costa ${ }^{1}$

\begin{abstract}
Background: Inadequate gestational weight gain (GWG) is associated with adverse outcomes in maternal and child health and can be enhanced by social inequalities, such as lower education and household food insecurity (HFI). Women are more vulnerable to $\mathrm{HFl}$, which has been associated with negative health effects for pregnant women during the prenatal and puerperal periods, particularly in regard to the aggravation of pregnancy risks. This study investigated the association between sociodemographic characteristics and HFI with respect to adequacy of total GWG among women with high-risk pregnancies.
\end{abstract}

Methods: This was a prospective cohort study that evaluated the total GWG of 169 pregnant women. The women were seen at a public university hospital in the metropolitan region of Rio de Janeiro (Brazil). Their sociodemographic and gestational characteristics and the Brazilian Scale of Domestic Food Insecurity were investigated. To estimate the total GWG, the difference between the patient weight at the last prenatal visit and the initial patient weight was verified, with both collected from the medical records of the pregnant women. The classification of the total GWG considered the recommendations of the Institute of Medicine (IOM) (2009). A multinomial logistic regression model assessed the risk (odds ratio; OR) and confidence intervals (Cl 95\%)) of insufficient and excessive GWG with exposure to HFI and other covariates ( $p$ value $<0.05$ ).

Results: Insufficient and excessive GWG were observed in $27.8 \%$ and $47.9 \%$ of the pregnant women, respectively. More than half of the women (74.6\%) had a high education level. Exposure to mild HFI occurred in $44.2 \%$ of the women. After adjustment, the HFI was not associated with insufficient or excessive GWG. The educational level of women was the only variable significantly associated with a lower risk of GWG insufficiency (OR: 0.10; $95 \%$ Cl: $0.01-$ 0.89).

Conclusions: In this population, higher maternal education was a protective factor against insufficient GWG. We highlight the importance of additional health support and counseling for women in the most vulnerable social conditions, considering the importance of access to information for reducing health risks.

Keywords: Gestational weight gain, Pregnant women, Food and nutrition security, Social determinants of health

\footnotetext{
* Correspondence: alexiaabreurodrigues@gmail.com

'Institute of Nutrition Josué de Castro, Federal University of Rio de Janeiro,

Av Carlos Chagas Filho, 373, CCS. Bloco J, $2^{\circ}$ andar. 21941-902 - Ilha do

Fundão, Rio de Janeiro, Brazil

Full list of author information is available at the end of the article
}

(c) The Author(s). 2021 Open Access This article is licensed under a Creative Commons Attribution 4.0 International License, which permits use, sharing, adaptation, distribution and reproduction in any medium or format, as long as you give appropriate credit to the original author(s) and the source, provide a link to the Creative Commons licence, and indicate if changes were made. The images or other third party material in this article are included in the article's Creative Commons licence, unless indicated otherwise in a credit line to the material. If material is not included in the article's Creative Commons licence and your intended use is not permitted by statutory regulation or exceeds the permitted use, you will need to obtain permission directly from the copyright holder. To view a copy of this licence, visit http://creativecommons.org/licenses/by/4.0/ The Creative Commons Public Domain Dedication waiver (http://creativecommons.org/publicdomain/zero/1.0/) applies to the data made available in this article, unless otherwise stated in a credit line to the data. 


\section{Background}

Weight gain during pregnancy is one of the main markers of physiological and somatic changes that reflect fetal development and growth [1, 2]. However, insufficient or excessive gestational weight gain (GWG) can threaten maternal and child health [3, 4], contributing to the presence of unfavorable gestational outcomes, particularly in women classified as having high-risk pregnancies [5].

As determinants of maternal health, sociodemographic conditions, such as limited access to health care [6-8], also play an important role during pregnancy [9]. Unfavorable aspects, such as less education, the absence of paid work and a low family income, are described in the literature as social determinants associated with insufficient or excessive GWG [2, 9]. Additionally, the evidence supports the hypothesis that household food insecurity (HFI) can be a particularly important barrier to maintaining health during pregnancy [10]. Studies performed to assess the effects of HFI on weight gain during pregnancy observed that HFI was related to both the possibility of insufficient weight gain [11] and metabolic adaptations that increase the risk of obesity [12].

HFI is defined as the lack of secure access to sufficient amounts of safe and nutritious food for normal growth and development and an active and healthy life [13]. Psychometric scales contribute to the assessment of HFI, which can be measured based on concerns about a lack of food to the restriction and experience of hunger in cases of more severe limitations [14, 15].

It is important to note that women are more vulnerable to HFI. The global assessment of the impact of HFI showed that women were approximately $27 \%$ more likely to be exposed to more severe HFI than men [16]. In Brazil, data from the last Family Budget Survey (in Portuguese- Pesquisa de Orçamentos Familiares) revealed a vulnerability and limited access to food in households headed by women, approximately $52 \%$ of whom were affected by severe HFI [17]. A similar finding was reported in the study by Lignani et al. (2020), which evaluated a model of HFI determinants. According to the authors, when the head of the family was female, there was a greater probability of having occupations with lower income levels [18]. The relationship between women and HFI is the result of unequal access to and control of financial resources and unstable incomes affecting the acquisition of food [19].

Additionally, the main causes of HFI for women have been revealed by different sources, such as poverty, low education, being out of the labor market, a large family, the number of children under five, low food diversity and a low frequency of daily meals [16]. During pregnancy, HFI can contribute to nutritional problems related to deficiencies in food intake during a stage of a woman's life with a higher demand for nutrients for fetal growth and development. HFI is a potential factor associated with the health risks of pregnant women and can contribute to the aggravation of disorders associated with gestational risk, such as anemia and gestational diabetes mellitus [10, 12]. A systematic literature review showed that the associations between HFI and the health of pregnant women were related to poor dietary quality, dietary diversity and inadequate nutrient intake; moreover, HFI was related to higher risks of depression and anxiety [20].

Although HFI is an important measure to be evaluated during pregnancy, few studies have explored its effects on the adequacy of GWG in at-risk women during pregnancy. The investigation of this relationship may assist in the identification of pregnant women exposed to unfavorable social health conditions and development of interventions to reduce the pregnancy risk related to insufficient GWG and excessive GWG. This study aimed to verify the association of HFI and unfavorable sociodemographic characteristics with total GWG inadequacy in high-risk pregnant women.

\section{Methods \\ Study design}

This prospective cohort study was carried out with pregnant women from a maternity and prenatal unit of a public university hospital (UH) located in the metropolitan region of Rio de Janeiro (Brazil).

The UH has a coverage area comprising seven municipalities in the metropolitan region of the state of Rio de Janeiro [21]. Comparing the characteristics of these municipalities, it is possible to perceive different sociodemographic conditions. In 2013, the evaluation of the municipal human development index (in Portuguese: Indice de Desenvolvimento Humano Municipal - IDHM), for example, indicated that in the municipality where the $\mathrm{UH}$ is located, the IDHM was 0.837, the highest index among the seven municipalities. On the other hand, among the municipalities served by the $\mathrm{UH}$, the lowest IDHM rate was 0.654 . The IDHM is a number from 0 to 1 , where 1 represents greater human development in the locality, and the measure is composed of three dimensions: longevity, income and education. In the municipality where the UH is located, life expectancy at birth was 76.2 years; the average per capita monthly income in real ( $\mathrm{R} \$$ ) was $\mathrm{R} \$ 2.000$ (United States dollar-USD 925.9); and among the population over 25, 2.6\% were illiterate, and $33.7 \%$ had the highest level of education. In contrast, the municipality with the lowest IDHM had a life expectancy at birth of 72.6 years, with an average per capita income of R\$ 440 (US\$ 203.7); in addition, $11.1 \%$ of the population was illiterate, and only $3.7 \%$ had the highest level of education [22]. This information 
indicates the differences and inequalities among pregnant women attending $\mathrm{UH}$.

In Brazil, all pregnant women are entitled to access prenatal care in the Unified Health System by the Primary Health Care Service (PHC). At the PHC, pregnant women are monitored periodically, and when any pregnancy risk is identified and diagnosed, they are referred by the National Regulation System (in Portuguese: National Regulation System - SISREG) ${ }^{1}$ to a more complex prenatal service. The classification of gestational risk is a dynamic process that identifies pregnant women who need interventions that require greater assistance and technological resources and more complex care according to their risk potential, health problems or degree of suffering [6]. The gestational risk factors considered for referral to high-risk prenatal care may be related to previous clinical conditions (heart diseases, hypertension, autoimmune diseases, diseases of the endocrine system), factors related to their previous reproductive history (eclampsia, habitual abortion, perinatal death in a previous pregnancy) and factors related to the current pregnancy (twins, specific hypertensive gestational syndrome, fetal growth retardation) [6].

The UH prenatal and maternity service specifically serves pregnant women referred and classified as having some gestational risk. Pregnant women are referred to a screening consultation to confirm the diagnosis of pregnancy risk. Nonconfirmation indicates the counterreference, that is, the return of these pregnant women to the primary $\mathrm{PHC}$, whereas confirmation of gestational risk indicates continuity of care in the most complex prenatal care units. In this study, prenatal and maternity ambulatory care was performed at the UH. All of the referred pregnant women who had a proven gestational risk and remained in the UH were approached, and those who consented to participate in our study were included in the sample. Figure 1 shows the flow of care of these pregnant women from the identification of gestational risk in $\mathrm{PHC}$ to the possible outcomes in prenatal care regarding the diagnosis of gestational risk until delivery at the UH maternity ward.

The data collection for this study was carried out between August 2017 and October 2019 for the sample selection in addition to the pregnant women presenting with some confirmed gestational risk. The eligibility criteria were age $\geq 18$ years, a single pregnancy and an expected delivery through October 2019.

\footnotetext{
${ }^{1}$ SISREG is a virtual management system of the Ministry of Health that manages from the basic and specialized outpatient network to hospital and hospitalization, at the levels: municipal, state, federal, including private services of the Unified Health System and university students, seeking greater control flow and optimization of the use of resources, in order to guarantee the humanization of services.
}

This study complies with the Declaration of Helsinki [23]. This study was approved by the Research Ethics Committee of the Federal University of Rio de Janeiro (process number: 63737316.5.0000.5257).

\section{Variables included in this study Gestational weight gain}

The total GWG was calculated as the difference between the final weight and the initial weight. The GWG is a measure for assessing and monitoring the health of pregnant women carried out by health professionals in several prenatal units, hospitals and maternity units [6]. The recommendation of the total GWG of the Institute of Medicine (2009) was adopted, so it was necessary to calculate the initial body mass index (BMI) by the weight and height ratio [6, 24].

Height and weight measurements at the beginning of pregnancy were collected from the pregnant woman's health booklet, a document used in prenatal care for monitoring and providing health guidelines during pregnancy. These were measured during the prenatal consultation at the $\mathrm{PHC}$ of origin of the pregnant women. Most of the pregnant women included in this sample $(77.3 \%)$ had these measures reported in the first gestational trimester (1-13 gestational weeks), an opportune time to check their initial weight [6].

The first prenatal consultation of the UH for approximately $76 \%$ of the pregnant women occurred after the first gestational trimester, a characteristic that was expected, since some of the risk factors appear or are diagnosed only after the first gestational trimester [6]. In this study, we chose to use the weight measured in the first trimester of pregnancy and recorded in the pregnant woman's health booklet as the initial weight. Thus, even if the consultation of the pregnant woman at UH took place after the first trimester of pregnancy, we considered the initial weight measurements measured at PHC until the 13th week of pregnancy. initial BMI

During the first prenatal consultation at $\mathrm{UH}$, an interview was carried out to apply the data collection questionnaire. At this moment, the pregnant woman's health booklet was requested to verify the initial anthropometric measurements of height and weight, and they were considered to estimate the initial BMI (weight $[\mathrm{kg}] /$ height $\mathrm{m}^{2}$ ) [6]. For pregnant women who started prenatal care at the PHC after the first gestational trimester and without data about the initial weight registered in the pregnant woman's health booklet (22.7\%), selfreported initial anthropometric measurements were requested from them and considered in the analyses. This assessment considers the premise that the measurement of the initial weight represents the weight measured in a period of up to two months before pregnancy and during pregnancy at the limit of 13 weeks of gestation [6]. 

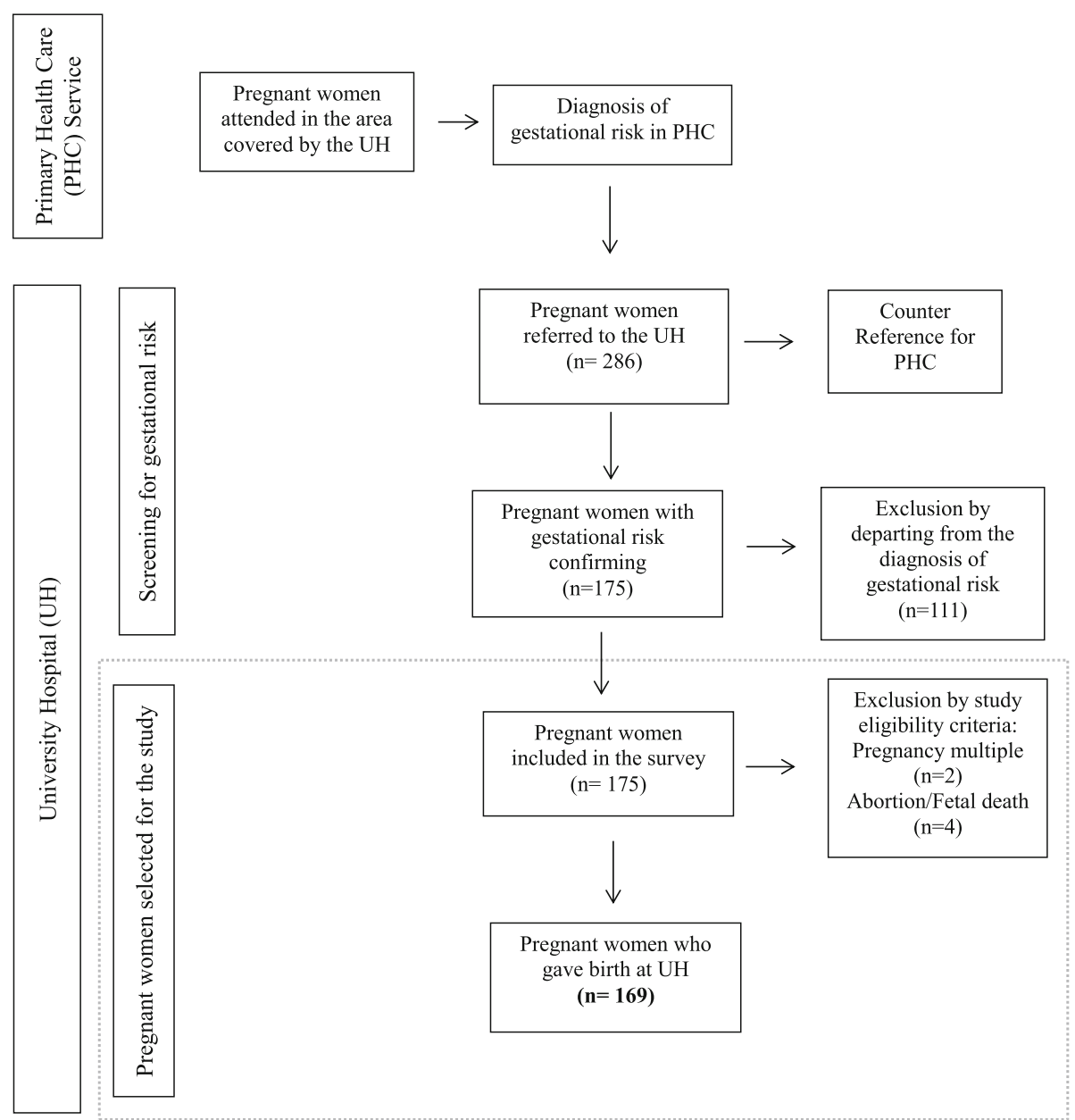

Fig. 1 Flowchart for selecting the sample of pregnant women at risk in a university hospital (UH). Metropolitan area of Rio de Janeiro, Brazil, 2019

To determine the final weight, the medical records of the pregnant woman in the maternity ward were consulted. The final weight was considered to be the weight measurement at the last prenatal consultation at $\mathrm{UH}$, two weeks before the date of delivery. In the absence of information about this measure in the medical record, the women were asked about it in the maternity ward after delivery, and the self-reported final weight was considered (8.3\%).

The initial BMI was categorized as follows: (i) low weight (BMI $<18.5 \mathrm{~kg} / \mathrm{m}^{2}$ ); (ii) normal weight (BMI 18.5-24.9 kg/m²); (iii) overweight (BMI $25.00-29.9 \mathrm{~kg} /$ $\mathrm{m}^{2}$ ); and (iv) obese $\left(B M I \geq 30.0 \mathrm{~kg} / \mathrm{m}^{2}\right)$. The total GWG was classified into three categories of weight gain (adequate, insufficient and excessive) according to the ranges established for the initial BMI: (i) low weight $12.5-18.0 \mathrm{~kg}$ of total GWG; (ii) normal $-11.0-16.00 \mathrm{~kg}$ of total GWG; (iii) overweight - 7.0-11.5 kg of total GWG; and (iv) obese - 5.0-9.0 kg of total GWG [17]. The total GWG was adjusted according to the gestational age as a measure of the final weight.

\section{Household Food insecurity}

HFI was estimated based on the Brazilian Household Food Insecurity Measurement Scale (in Portuguese: Escala Brasileira de Insegurança Alimentar-EBIA). The EBIA is a validated instrument for the Brazilian population that investigates the dimensions of access to food through the perception of a family member regarding the lack of financial resources available for the purchase of food [14]. This psychometric scale comprises 14 items and categorizes households according to HFI exposure, ranging from concern about the lack of food at home and insufficient quality of meals due to a lack of food and hunger. The HFI severity levels are measured in the EBIA by the sum of affirmative responses to each item on the scale (8 items for households with adults only and 14 items for households with at least one person less than 18 years old). The absence of positive responses characterizes the condition of household food security (HFS), which indicates that the respondent has no concern or perception of income limitations regarding food purchase and access. The cutoff points classify the HFI 
into three levels: (i) mild HFI; (ii) moderate HFI; and (iii) severe HFI. More details about EBIA have been described in the literature [14, 25-27]. In this study, the levels of moderate HFI + severe HFI (moderate/severe HFI) were considered in the same category.

Sociodemographic and health for pregnancy variables

Sociodemographic and gestational characteristics were included to describe the sample and to investigate social vulnerabilities that could contribute to health inequalities and negatively affect GWG. Maternal age in years was investigated and categorized ( $<35$ years; $\geq 35$ years), considering that pregnant women aged $>35$ years tend to have more unfavorable gestational outcomes [6]. The level of education was classified into three categories: < 9 years (did not complete elementary school); 9-15 years (completed elementary school or completed high school); and > 15 years (completed high school). Despite the lowest level of education ( $<5$ years of regular study) being a risk factor for pregnant women [6], the categories established in this study considered the highest level of education of the sample of pregnant women, and we classified them by using a category of less education as incomplete primary education ( $<9$ years old). Schooling was described in association with health conditions and GWG [28, 29]. Unsafe marital relationships also compromise the health of pregnant women [6]. The variable marital status considers the impact of living alone and the difficulties faced by single women and mothers in accessing material and financial resources due to gender inequality [17]. In this evaluation, the categories were established (single/separated/widowed; married/stable union) [28]. Drinking water consumption (yes; no) was studied as a gestational risk factor reflecting the unfavorable environmental conditions to which pregnant women are exposed [6].

Data on the race/ethnicity variable were self-declared and evaluated in the categories of white or black/mixed race, considering the vulnerability that racial inequality confers on the health of populations [30, 31]. Family income was investigated in relation to the minimum wage, and two categories were studied ( $\leq 2$ minimum wages; > 2 minimum wages). The minimum wage is the minimum amount regulated by law for paid work [32]. Taking 2018 as a reference, the annual value for the minimum wage in Brazil in the current currency (Real; $\mathrm{R} \$$ ) was $\mathrm{R} \$ 954$, which corresponds in this period to USD 261.4 [33, 34] (the exchange rate at the time was USD 3.65 per R\$1.00). Family income is an important measure to investigate access to resources such as the purchase of food by families [35].

In relation to health, the following information was investigated as determinants of GWG: The number of prenatal consultations $(<8 ; \geq 8)$ was considered in categories established based on the recommendation of 8 or more consultations for the monitoring and health care of pregnant women and babies, including the identification of risk factors and monitoring of GWG [6]. The number of previous pregnancies $(1 ; 2$ to 3$)$ was obtained, as studies indicate the highest risk of excessive GWG in multiparous pregnant women $[28,30,36]$. Gestational age at the time of delivery ( $<40$ weeks; $\geq 40$ weeks) was also obtained. Initial BMI [24] was assessed in three categories (low weight; normal; overweight/obese); the decision to sum the categories of overweight BMI and obese BMI was due to the sample size. The consumption of alcoholic beverages (yes; no) and smoking during pregnancy (yes; no) were also investigated in relation to GWG [6, 36].

With the exception of the variable total number of prenatal consultations and gestational age at delivery, which were investigated at the maternity hospital, all of the other data were obtained at the first consultation of the pregnant woman at the $\mathrm{UH}$.

\section{Statistical analysis}

We estimated the proportions and confidence intervals (95\% CIs) to describe the study variables. In the first step, the chi-square test was used to compare sociodemographic, HFI and pregnancy characteristics between GWG categories (adequate GWG, insufficient GWG and excessive GWG). The variables with a level of significance in this first analysis, defined as $p<0.20$, were included in the multivariate analysis. The decision to adopt a more conservative level of statistical significance followed the recommendations used in the literature [37, 38]. In the second step, a multinomial regression model was used to verify the variables associated with GWG. We assigned the adequacy GWG category as a reference in relation to the inadequate (insufficient and excessive) GWG categories. The data are expressed as odds ratios (ORs) and 95\% CIs. Variables that in the bivariate analysis were associated with GWG, with a significance level of up to $20 \%$ ( $p$ value $<0.20$ ), were considered in the adjusted model. In the final model, the level of significance was defined as a $p$ value $<0.05$. All data processing and analysis were performed using the Stata statistical package (version 16) [39].

\section{Results}

During the reference period of this study, 286 pregnant women were referred to their first consultation in the obstetrics sector of the UH prenatal clinic, and 117 (41\%) of them were ineligible (Fig. 1). The final sample included 169 women with an average age of 30.2 years, and their race/ethnicity was predominantly black/mixedrace. Most were married or lived in a stable relationship, had completed high school, and had a family income $\leq$ twice the minimum wage. Regarding the gestational 
profile, most women attended at least eight prenatal consultations and did not consume alcohol or smoke during pregnancy. More than half of the women included in this study were exposed to some level of HFI. Considering their initial BMI, there was a high proportion of pregnant women with obesity. Inadequate total GWG (insufficient and excessive) was found in most women; $47 \%$ of women had excessive GWG, and approximately $28 \%$ of pregnant women had insufficient GWG (Table 1).

The categories of gestational weight gain were correlated ( $p$ value $<0.20$ ) with the following variables: maternal age, marital status, educational level, smoking and alcohol consumption during pregnancy, number of prenatal visits, weeks' gestation at delivery and household FI (Table 2). Insufficient GWG was more common in women with a lower educational level (48.1\%), married marital status (34.1\%), age up to 35 years $(26.6 \%)$ and those who reported alcohol beverages consumption (45.4\%) and cigarettes (60\%). In turn, excessive GWG was more common in women over 35 years old (59.0\%), with a single marital status (56.9\%) and with a higher educational level (66.7\%). Additionally, more common were the number of prenatal consultations $\leq 8$ (58.7\%) and a gestational age at delivery greater than 40 weeks' gestation (53.5\%) for women with excessive GWG. Regarding FI, exposure to moderate/severe FI was more common for women with both insufficient GWG (31.6\%) and excessive GWG (68.4\%).

Table 3 presents the unadjusted and adjusted multinomial logistic regression. In the bivariate analysis, more years of schooling and the woman's age were considered protective factors for insufficient GWG. Living without a partner, being a current smoker and having $<8$ total prenatal consultations were considered factors that increased the OR of insufficient GWG. An increased risk for insufficient GWG and excessive GWG was observed with an increase in the number of gestational weeks at delivery (> 40 weeks' gestation). HFI was not related to GWG. After adjusting the model, only the educational level of the pregnant woman was significantly and inversely associated with insufficient GWG; thus, the higher the education level of the pregnant woman was, the lower the risk of inadequate GWG was ( $p$ value < 0.05).

\section{Discussion}

Our study showed that inadequate GWG (insufficient or excessive) was not associated with exposure to FI during pregnancy in this sample of women with high-risk pregnancies. However, after assessing the sociodemographic and health conditions of pregnant women, a higher level of education was a protective factor against insufficient GWG.
This study demonstrated a higher prevalence of women with excessive GWG. An analysis of secondary data from multicenter studies in the United States involving 8293 women showed that $73 \%$ had excessive GWG, corresponding to approximately three in four women [40]. Zhao et al. [4] identified approximately 50\% of pregnant women with excessive GWG in a study conducted in China, and 15.2\% had insufficient GWG. In Brazil, Campos et al. [41] evaluated the adequacy of GWG among pregnant women in the northern region of the country and observed a prevalence of excessive GWG in almost half of the sample (59\%) and insufficient GWG in $19 \%$ of women. A similar result was observed for pregnant women in Rio de Janeiro; according to the authors, almost $50 \%$ of women evaluated had excessive GWG, and less than 30\% had adequate GWG [42].

A direct determinant of GWG is the initial BMI [14]. In this study, no associations were observed between these variables. However, we observed that more than half of the pregnant women had an initial BMI corresponding to overweight and obesity. In contrast, a low initial BMI was observed in only $2.6 \%$ of the sample, a proportion close to the results of the Brazilian Food and Nutrition Surveillance System (in Portuguese: Sistema de Vigilância Alimentar e Nutricional - SISVAN) during 2019, when 2.5\% of adult Brazilian women were found to have a low BMI. Data from the Brazilian SISVAN also revealed an increase in the prevalence of overweight BMI among women of reproductive age; $34.2 \%$ were considered overweight, and $29.7 \%$ were obese based on BMI [43].

In this study, it was also found that more than half of the mothers (56.4\%) were exposed to some level of HFI during pregnancy. Oliveira et al. [44] investigated HFI in a group of pregnant women attending $\mathrm{PHC}$ in northeastern Brazil and identified a prevalence of $42.7 \%$ of HFI in the sample, a value lower than the result in this study. In addition, in the present study, we opted for the sum of the most severe levels of HFI (moderate + severe). Thus, it was observed that $12.3 \%$ of women had limited access to food in terms of quantity and quality and possibly continued to experience hunger; this proportion was lower than that reported by Marano et al. [45] when investigating HFI in pregnant women in two cities in Rio de Janeiro (14.9\% moderate/severe HFI).

Other studies carried out in Brazil evaluating HFI during pregnancy showed significant variations in the prevalence estimated by the EBIA, depending on the region of the country. In studies carried out in the northeastern and southeastern regions of Brazil, the authors reported a higher prevalence of HFI among pregnant women, ranging from $59 \%$ to $71.6 \%[46,47]$ and $37.8 \%$ in southeastern Brazil [48]. These differences in prevalence are consistent with the distribution of severe HFI in Brazil. 
Table 1 Proportion (\%) and 95\% confidence interval (CI) in pregnant women. University Hospital from a Metropolitan area of Rio de Janeiro, Brazil, 2019

\begin{tabular}{|c|c|c|}
\hline Variables & $\begin{array}{l}\text { Proportion } \\
\text { (\%) }\end{array}$ & $95 \% \mathrm{Cl}$ \\
\hline \multicolumn{3}{|l|}{ Total GWG } \\
\hline Insufficient & 23.7 & $\begin{array}{l}17.8- \\
31.1\end{array}$ \\
\hline Adequacy & 21.9 & $\begin{array}{l}16.1- \\
29.0\end{array}$ \\
\hline Excessive & 54.4 & $\begin{array}{l}46.5- \\
62.0\end{array}$ \\
\hline \multicolumn{3}{|l|}{ Maternal age } \\
\hline$\leq 35$ years old & 72.8 & $\begin{array}{l}65.1- \\
79.4\end{array}$ \\
\hline$>35$ years old & 27.2 & $\begin{array}{l}20.6- \\
34.8\end{array}$ \\
\hline \multicolumn{3}{|l|}{ Race/ethnicity } \\
\hline White & 32.5 & $\begin{array}{l}25.8- \\
40.0\end{array}$ \\
\hline Black/mixed-race & 67.5 & $\begin{array}{l}60.0- \\
74.1\end{array}$ \\
\hline \multicolumn{3}{|l|}{ Marital status } \\
\hline Single/Divorced/Widowed & 28.4 & $\begin{array}{l}22.0- \\
35.7\end{array}$ \\
\hline Married & 71.6 & $\begin{array}{l}64.3- \\
78.0\end{array}$ \\
\hline \multicolumn{3}{|l|}{ Educational level } \\
\hline$<9$ years & 16.6 & $\begin{array}{l}11.6- \\
23.0\end{array}$ \\
\hline $9-15$ years & 74.5 & $\begin{array}{l}67.4- \\
80.6\end{array}$ \\
\hline$>15$ years & 8.9 & $5.4-14.2$ \\
\hline \multicolumn{3}{|l|}{ Consumption of potable water } \\
\hline Yes & 79.0 & $\begin{array}{l}72.1- \\
84.6\end{array}$ \\
\hline No & 21.0 & $\begin{array}{l}15.4- \\
27.8\end{array}$ \\
\hline \multicolumn{3}{|l|}{ Family income } \\
\hline$\leq 2$ minimum wages & 69.1 & $\begin{array}{l}61.5- \\
75.8\end{array}$ \\
\hline$>2$ minimum wages & 30.9 & $\begin{array}{l}24.2- \\
38.4\end{array}$ \\
\hline \multicolumn{3}{|c|}{ Level of Security/Food insecurity (FI) } \\
\hline Food security & 43.5 & $\begin{array}{l}36.1- \\
51.3\end{array}$ \\
\hline Mild FI & 44.2 & $\begin{array}{l}36.7- \\
52.0\end{array}$ \\
\hline Moderate/severe FI & 12.3 & $\begin{array}{l}8.02- \\
18.3\end{array}$ \\
\hline \multicolumn{3}{|c|}{$\begin{array}{l}\text { Gestational trimester in first antenatal care } \\
\mathrm{PHC}^{\mathrm{C}}\end{array}$} \\
\hline $1^{\text {st }}$ trimester & 77.3 & $\begin{array}{l}69.3- \\
83.7\end{array}$ \\
\hline
\end{tabular}

Table 1 Proportion (\%) and 95\% confidence interval (Cl) in pregnant women. University Hospital from a Metropolitan area of Rio de Janeiro, Brazil, 2019 (Continued)

\begin{tabular}{lll}
\hline Variables & $\begin{array}{l}\text { Proportion } \\
(\%)\end{array}$ & $\mathbf{9 5 \%} \mathbf{~ C l}$ \\
\hline $2^{\text {nd }}-3^{\text {rd }}$ trimester & 22.7 & $16.3-$ \\
& & 30.7 \\
Gestational trimester in first antenatal care & & \\
$\mathrm{UH}^{\mathrm{d}}$ & & \\
$1^{\text {st }}$ trimester & 23.2 & $17.3-$ \\
& & 30.3 \\
$2^{\text {nd }}-3^{\text {rd }}$ trimester & 76.8 & $69.7-$ \\
& & 82.7 \\
Number visits prenatal & & \\
$<8$ & 50.9 & $43.3-$ \\
& & 58.4 \\
$\geq 8$ & 49.1 & $41.6-$ \\
& & 56.6
\end{tabular}

Number previous pregnancy

$\begin{array}{lll}1 & 34.3 & 26.7- \\ & & 42.8 \\ 2-3 & 46.3 & 37.9- \\ & & 54.8 \\ 4 & 19.4 & 13.5- \\ & & 27.0\end{array}$

Consumption of alcohol

Yes

7.1

$4.1-12.2$

No

92.9

$87.8-$

96.0

Current smoker

Yes

No

$6.5 \quad 3.6-11.4$

$93.5 \quad 88.6-$

96.4

Pre pregnancy $\mathrm{BMI}^{\mathrm{b}}$

Low weight

$2.5 \quad 0.9-6.7$

Normal

$35.3 \quad 28.1$

28.1

Overweight/ Obesity

$62.2 \quad 54.2-$

69.5

Weeks' gestation at delivery

$<40$ weeks

$27.5 \quad 20.2$

$\geq 40$ weeks

36.2

$63.7-$

79.8

${ }^{a}$ Gestational weight gain estimated according Institute of Medicine (2009)

${ }^{\mathrm{b}}$ Body Mass Index $\left(\mathrm{Kg} / \mathrm{m}^{2}\right)$

'Primary Health Care Service

dUniversity Hospital

Although a higher prevalence of HFI (56.5\%) was observed among the women in this study, no relationship with GWG adequacy was found.

Few studies have evaluated the relationship between GWG and HFI. A meta-analysis identified that pregnant women exposed to home HFI had an increased 
Table 2 Association between variables and adequacy and inadequacy (insufficient and excessive) gestational weight gain in pregnancy women. University Hospital from a Metropolitan area of Rio de Janeiro, Brazil, 2019

\begin{tabular}{|c|c|c|c|c|}
\hline \multirow{4}{*}{ Variables } & \multicolumn{4}{|c|}{ Gestational weight gain } \\
\hline & \multirow[t]{2}{*}{ Adequacy } & \multicolumn{2}{|l|}{ Inadequacy } & \multirow{3}{*}{$\begin{array}{l}p \\
\text { value }\end{array}$} \\
\hline & & Insufficient & Excessive & \\
\hline & $\%^{a}$ & $\%^{\mathrm{a}}$ & $\%^{\mathrm{a}}$ & \\
\hline Maternal age & & & & $0.197^{* *}$ \\
\hline$\leq 35$ years old & 21.1 & 26.6 & 52.3 & \\
\hline$>35$ years old & 28.2 & 12.8 & 59.0 & \\
\hline Race/ethnicity & & & & 0.812 \\
\hline White & 19.2 & 23.1 & 57.7 & \\
\hline Black/mixed & 23.1 & 24.1 & 52.8 & \\
\hline Marital status & & & & $0.165^{* *}$ \\
\hline Single/Divorced/Widowed & 23.3 & 19.8 & 56.9 & \\
\hline Married & 18.2 & 34.1 & 47.8 & \\
\hline Educational level & & & & $0.021^{* *}$ \\
\hline$<9$ & 11.1 & 48.1 & 40.7 & \\
\hline $9-15$ & 24.6 & 19.5 & 55.9 & \\
\hline$\geq 16$ & 20.0 & 13.3 & 66.7 & \\
\hline Consumption of potable water & & & & 0.479 \\
\hline Yes & 20.0 & 24.0 & 56.0 & \\
\hline No & 29.4 & 23.5 & 47.1 & \\
\hline Family income & & & & 0.950 \\
\hline$\leq 2$ minimum wages & 22.7 & 23.6 & 53.6 & \\
\hline$>2$ minimum wages & 20.4 & 25.0 & 54.5 & \\
\hline Level of Security/Food insecurity (FI) & & & & $0.099^{* *}$ \\
\hline Food security & 21.7 & 23.2 & 55.1 & \\
\hline Mild FI & 30.3 & 21.2 & 48.5 & \\
\hline Moderate/severe FI & - & 31.6 & 68.4 & \\
\hline Gestational trimester in first antenatal care $\mathrm{PHC}^{\mathrm{C}}$ & & & & 0.928 \\
\hline $1^{\text {st }}$ trimester & 21.8 & 20.8 & 57.4 & \\
\hline $2^{\text {nd }}-3^{\text {rd }}$ trimester & 20.7 & 24.1 & 55.2 & \\
\hline \multicolumn{5}{|l|}{ Gestational trimester in first antenatal care $U^{d}$} \\
\hline $1^{\text {st }}$ trimester & 22.2 & 22.2 & 55.6 & 0.971 \\
\hline $2^{\text {nd }}-3^{\text {rd }}$ trimester & 21.7 & 24.2 & 54.2 & \\
\hline Number visits prenatal & & & & $0.178^{* *}$ \\
\hline$<8$ & 23.7 & 17.5 & 58.7 & \\
\hline$\geq 8$ & 20.0 & 30.0 & 50.0 & \\
\hline Number previous pregnancy & & & & 0.633 \\
\hline 1 & 17.4 & 28.3 & 54.4 & \\
\hline $2-3$ & 27.1 & 25.4 & 47.5 & \\
\hline$\geq 4$ & 13.0 & 30.4 & 56.5 & \\
\hline Consumption of alcohol & & & & $0.129^{* *}$ \\
\hline Yes & 27.3 & 45.4 & 27.3 & \\
\hline No & 21.5 & 22.1 & 56.4 & \\
\hline Current smoker & & & & $0.021^{* *}$ \\
\hline
\end{tabular}


Table 2 Association between variables and adequacy and inadequacy (insufficient and excessive) gestational weight gain in pregnancy women. University Hospital from a Metropolitan area of Rio de Janeiro, Brazil, 2019 (Continued)

\begin{tabular}{|c|c|c|c|c|}
\hline \multirow{4}{*}{ Variables } & \multicolumn{4}{|c|}{ Gestational weight gain } \\
\hline & \multirow[t]{2}{*}{ Adequacy } & \multicolumn{2}{|l|}{ Inadequacy } & \multirow{3}{*}{$\begin{array}{l}p \\
\text { value }^{*}\end{array}$} \\
\hline & & Insufficient & $\overline{\text { Excessive }}$ & \\
\hline & $\%^{\mathrm{a}}$ & $\%^{\mathrm{a}}$ & $\%^{\mathrm{a}}$ & \\
\hline Yes & 10.0 & 60.0 & 30.0 & \\
\hline No & 22.7 & 21.3 & 56.0 & \\
\hline Pre pregnancy $\mathrm{BMI}^{\mathrm{b}}$ & & & & 0.874 \\
\hline Low weight & 25.0 & 25.0 & 50.0 & \\
\hline Normal & 27.3 & 21.8 & 50.9 & \\
\hline Overweight/Obese & 19.6 & 24.7 & 55.7 & \\
\hline Weeks' gestation at delivery & & & & $0.193^{* *}$ \\
\hline$<40$ weeks & 33.3 & 18.2 & 48.5 & \\
\hline$\geq 40$ weeks & 18.6 & 27.9 & 53.5 & \\
\hline
\end{tabular}

${ }^{\text {a Proportions }}$

${ }^{\mathrm{b}}$ Body Mass Index $\left(\mathrm{Kg} / \mathrm{m}^{2}\right)$

c Primary Health Care Service

d University Hospital

* Chi squared test

${ }^{* *} \boldsymbol{p}$ value $<0.20$

prevalence of discrepant weight gain, both excessive and inadequate weight gain [49]. Other studies have reported a lack of an association between GWG and HFI, as observed by Laraia et al. [50]. According to these authors, no significant association was found between HFI and GWG among pregnant women in the United States. However, the authors observed that the average weight of women with HFI in the study was higher, as well as the GWG adequacy rate, suggesting HFI as an indicator for excessive GWG [50]. In Brazil, a study of pregnant women in the northeastern region of the country to identify the association among different factors, including HFI status and GWG, showed no significant association with HFI and the GWG outcome; this finding was similar to that of this study [44].

The main finding of this study indicates a reduction in the risk of insufficient GWG for women with more years of schooling, since pregnant women with access to secondary and higher education were more protected from this level of GWG than women with less than nine years of schooling. In the literature, a lower risk of insufficient GWG was also associated with higher levels of schooling [51]. On the other hand, a higher level of education was related to a higher risk of excessive GWG $[8,45]$.

In addition, higher education has been described as being associated with a greater likelihood of GWG adequacy [28] and a lower likelihood of excessive GWG [52]. Pregnant women with less than four years of education had a risk of excessive GWG that was approximately five times greater than that of other pregnant women [53]. These findings indicate that the increase in years of schooling may act as a protective factor for
GWG. In addition, the risk associated with low education and a greater propensity for excessive GWG [54, 55] and insufficient GWG [56] point to the importance of education as a social determinant of health [57]. Thus, understanding that inadequate GWG is a modifiable risk factor and that both excessive and insufficient weight gain during pregnancy can threaten the health of women and their children [58] is important for strengthening health services and factors related to the environment, education and health promotion [59].

This study has some limitations. For the pregnant woman's health booklet and height measurements, when these measures were not available, the self-reported data of the pregnant women were considered. In such cases, the possibility of biases attributed to overestimation or underestimation of measures must be considered [60, 61]. Researchers have corroborated the quality of the measures of weight and height measured by anthropometry versus those obtained by self-report in populationbased studies. For example, Conde et al. (2013) compared the measured and reported weight and height measurements of the Brazilian population and highlighted that the BMI estimates, measured or reported, were relatively close. In addition, a validation study of self-reported measures found that $84 \%$ of women who reported their weight and height measurements were categorized appropriately in regards to their BMI classification [62]. Health behaviors and interventions such as nutritional monitoring, possible interactions of the diet to control gestational weight gain and physical exercise during pregnancy were not evaluated in this study. However, there is some evidence regarding 
Table 3 Odds ratio (OR) and 95\% confidence interval (Cl) of the association between variables and insufficient and excessive gestational weight gain (GWG) in pregnant women. University Hospital from a Metropolitan area of Rio de Janeiro, Brazil, 2019

\begin{tabular}{|c|c|c|c|c|c|c|c|c|c|c|c|c|}
\hline & \multicolumn{6}{|c|}{ Bivariate model } & \multicolumn{6}{|c|}{ Adjusted model } \\
\hline & \multicolumn{3}{|c|}{ Insufficient GWG } & \multicolumn{3}{|c|}{ Excessive GWG } & \multicolumn{3}{|c|}{ Insufficient GWG } & \multicolumn{3}{|c|}{ Excessive GWG } \\
\hline & $\overline{O R}$ & $\mathrm{Cl} 95 \%$ & $\begin{array}{l}p \\
\text { value }\end{array}$ & $\overline{O R}$ & $\mathrm{Cl} 95 \%$ & $\begin{array}{l}p \\
\text { value }\end{array}$ & $\overline{O R}$ & $\mathrm{Cl} 95 \%$ & $\begin{array}{l}p \\
\text { value }\end{array}$ & $\overline{\mathrm{OR}}$ & $\mathrm{Cl} 95 \%$ & $\begin{array}{l}p \\
\text { value }\end{array}$ \\
\hline \multicolumn{13}{|l|}{ Maternal age } \\
\hline$\leq 35$ years old & Ref.[1] & & & Ref.[1] & & & Ref.[1] & & & Ref.[1] & & \\
\hline > 35 years old & 0.36 & $0.11-1.18$ & $0.09^{*}$ & 0.84 & $0.35-2.00$ & 0.70 & 0.66 & $0.13-3.28$ & 0.62 & 1.37 & $0.43-4.42$ & 0.60 \\
\hline \multicolumn{13}{|l|}{ Marital status } \\
\hline Single/Divorced/Widowed & 2.20 & $0.8-6.12$ & $0.13^{*}$ & 1.07 & $0.42-2.72$ & 0.88 & 1.83 & $0.50-6.68$ & 0.36 & 0.84 & $0.28-2.58$ & 0.76 \\
\hline Married & Ref.[1] & Ref.[1] & & Ref.[1] & Ref.[1] & & Ref.[1] & Ref.[1] & & Ref.[1] & & \\
\hline \multicolumn{13}{|l|}{ Educational level } \\
\hline$<9$ & Ref.[1] & Ref.[1] & & Ref.[1] & Ref.[1] & & Ref.[1] & Ref.[1] & & Ref.[1] & & \\
\hline $9-15$ & 0.18 & $0.05-0.72$ & $0.02^{* *}$ & 0.62 & $0.16-2.40$ & 0.49 & 0.10 & $0.01-0.89$ & $0.04^{* *}$ & 0.20 & $0.02-1.70$ & 0.14 \\
\hline$\geq 16$ & 0.15 & $0.02-1.37$ & $0.09^{*}$ & 0.91 & $0.15-5.58$ & 0.92 & 0.05 & $\begin{array}{l}0.002- \\
1.22\end{array}$ & 0.06 & 0.18 & $0.01-2.35$ & 0.19 \\
\hline \multicolumn{13}{|c|}{$\begin{array}{l}\text { Level of Security/Food insecurity } \\
\text { (FI) }\end{array}$} \\
\hline Food security & Ref.[1] & Ref.[1] & & Ref.[1] & & & & & & & & \\
\hline Mild FI & 0.65 & $0.24-1.75$ & 0.40 & 0.63 & $0.28-1.43$ & 0.27 & & & & & & \\
\hline Moderate/severe FI & 0.29 & $0.26-0.32$ & 0.98 & 0.26 & $0.23-0.29$ & 0.98 & & & & & & \\
\hline \multicolumn{13}{|l|}{ Number visits prenatal } \\
\hline$<8$ & 2.03 & $0.80-5.20$ & $0.14^{*}$ & 1.01 & $0.46-2.22$ & 0.98 & 4.03 & $\begin{array}{l}0.94- \\
17.25\end{array}$ & 0.06 & 0.95 & $0.33-2.68$ & 0.92 \\
\hline$\geq 8$ & Ref.[1] & Ref.[1] & & Ref.[1] & Ref.[1] & & Ref.[1] & Ref.[1] & & Ref.[1] & & \\
\hline \multicolumn{13}{|l|}{ Consumption of alcohol } \\
\hline Yes & 1.62 & $0.36-7.33$ & 0.53 & 0.38 & $0.07-2.00$ & 0.25 & & & & & & \\
\hline No & Ref.[1] & Ref.[1] & & Ref.[1] & & & & & & & & \\
\hline \multicolumn{13}{|l|}{ Current smoker } \\
\hline Yes & 6.37 & $\begin{array}{l}7.27- \\
55.90\end{array}$ & $0.09^{*}$ & 1.21 & $\begin{array}{l}0.12- \\
12.09\end{array}$ & 0.87 & 5.01 & $\begin{array}{l}0.36- \\
69.24\end{array}$ & 0.23 & 0.92 & $\begin{array}{l}0.07- \\
11.99\end{array}$ & 0.95 \\
\hline No & Ref.[1] & Ref.[1] & & Ref.[1] & Ref.[1] & & Ref.[1] & Ref.[1] & & Ref.[1] & & \\
\hline \multicolumn{13}{|l|}{ Weeks' gestation at delivery } \\
\hline$<40$ weeks & Ref.[1] & Ref.[1] & & Ref.[1] & Ref.[1] & & Ref.[1] & Ref.[1] & & Ref.[1] & & \\
\hline$\geq 40$ weeks & 2.75 & $0.85-8.94$ & $0.09^{*}$ & 1.98 & $0.76-5.14$ & $0.16^{*}$ & 2.13 & $0.49-9.29$ & 0.31 & 2.10 & $0.69-6.43$ & 0.19 \\
\hline
\end{tabular}

the low impact of these measurements on weight gain during pregnancy [63]. The investigation of family income in terms of minimum wages limited the assessment of income in relation to the number of family members (income per capita).

\section{Conclusion}

In this population, an important factor for GWG is maternal education, among the other determinants evaluated and widely discussed in the literature as predictors of GWG. Additionally, a lower level of education of the pregnant women evaluated may have preceded the effects of HFI on its relationship with the GWG of these women with high risks during pregnancy. Given the risk of inadequate gain during a high-risk pregnancy and given that GWG is a modifiable factor, the importance of additional support and health counseling is highlighted, particularly nutrition education interventions, such as a health-promoting tool for pregnant women and fetuses, particularly for women who are more socially vulnerable and who have low levels of formal education. 


\section{Abbreviations}

BMl: body mass index; Cl: confidence intervals; EBIA: Brazilian Household Food Insecurity Measurement Scale (in Portuguese: Escala Brasileira de Insegurança Alimentar); GWG: gestational weight gain; HFI: household food insecurity; HFS: household food security; IDHM: municipal human development index (in Portuguese: Indice de Desenvolvimento Humano Municipal); IOM: Institute of Medicine; OR: odds ratio; PHC: primary health care; R: Real; SISREG: National Regulation System (in Portuguese: Sistema Nacional de Regulação); SISVAN: Brazilian System of Food and Nutritional Surveillance (in Portuguese: Sistema de Vigilância Alimentar e Nutricional); UH: university hospital; USD: United States dollar

\section{Acknowledgements}

Not applicable.

\section{Authors' contributions}

AAR participated in the coordination, collected and interpreted the data. RSC and AAR contribute to the study design, statistical analysis and writing of the manuscript. ALPA conceived the idea of the study, participated in the coordination and helped in the writing of the manuscript. All authors participated in the study design, read and approved the final manuscript.

\section{Authors' information}

AAR is a student of the Graduate Program in Nutrition, Institute of Nutrition Josué de Castro, Federal University of Rio de Janeiro, Rio de Janeiro, Brazil. ALPA professor at the Department of Clinical Nutrition, Faculty of Nutrition Emília de Jesus Ferreiro, Fluminense Federal University, Rio de Janeiro, Brazil. RSC professor at the Department of Social and Applied Nutrition, Institute of Nutrition Josué de Castro, Federal University of Rio de Janeiro, Rio de Janeiro, Brazil.

\section{Funding}

This study received no funding.

\section{Availability of data and materials}

The data sets analyzed during the present study are not publicly available due to the compromised privacy and exposure of the participants, but are available from the corresponding author upon reasonable request.

\section{Declarations}

\section{Ethics approval and consent to participate}

The study protocol was carried out in accordance with the principles of the Declaration of Helsinki (1996) and approved by the ethics committee of University Hospital Clementino Fraga Filho/ Federal University of Rio de Janeiro (process number: 63737316.5.0000.5257). Written informed consent was obtained from all participants prior to the interview.

\section{Consent for publication}

Not applicable.

\section{Competing interests}

The authors declare that they have no competing interests.

\section{Author details}

'Institute of Nutrition Josué de Castro, Federal University of Rio de Janeiro, Av Carlos Chagas Filho, 373, CCS. Bloco J, $2^{\circ}$ andar. 21941-902 - Ilha do Fundão, Rio de Janeiro, Brazil. ${ }^{2}$ Nutrition Faculty Emília de Jesus Ferreiro, Federal Fluminense University, Rua Mário Santos Braga, 30, $4^{\circ}$ andar, 24020-140 - Niterói, Rio de Janeiro, Brazil.

\section{Received: 24 November 2020 Accepted: 8 June 2021}

\section{Published online: 29 June 2021}

\section{References}

1. Carvalhaes MABL, Gomes CB, Malta MB, Papini SJ, Parada CMGL. Sobrepeso pré-gestacional associa-se a ganho ponderal excessivo na gestação. Rev Bras Ginecol Obstet. 2013;35:523-9.

2. Magalhães EIS, Maia DS, Bonfim CFA, Neto MP, Lamounier JA, Rocha DS. Prevalência e fatores associados ao GPG excessivo em unidades de saúde do sudoeste da Bahia. Rev Bras Epidemiol. 2015;18:858-69.
3. Santos S, Voerman E, Amiano P, Barros H, Beilin LJ, Bergstrom A, et al. Impact of maternal body mass index and gestational weight gain on pregnancy complications: na individual participant dat meta-analysis of Europan, North American and Australian cohorts. BJOG. 2019. https://doi. org/10.1111/1471-0528.15661.

4. Zhao R, Xu I, Wu MI, Huang SH, Cao XJ. Maternal pre-pregnancy body mass index, gestational weight gain influence birth weight. Women Brith. 2017. https://doi.org/10.1016/j.wombi.2017.06.003.

5. Yang W, Han F, Gao X, Chen Y, Ji L, Cai X. Relationship between gestational weight gain and pregnancy complications or delivery outcome. Sci Rep. 2017. https://doi.org/10.1038/s41598-017-12921-3.

6. Brasil, Ministério da Saúde. Secretaria de atenção a saúde. Departamento de atenção básica. Atenção pré-natal. In: Cadernos de atenção básica/Atenção ao pré-natal de baixo risco. 2013. http://bvsms.saude.gov.br/bvs/publica coes/cadernos atencao_basica 32 prenatal.pdf. Accessed 15 Mar 2021.

7. O'Brien EC, Alberdi G, McAuliffe FM. The influence of socioeconomic status on gestational weight gain: a systematic review. J Public Health. 2018;40:41-55.

8. Esposti CDD, Santos-Netos ET, Oliveira AE, Travassos C, Pinheiro R Desigualdades sociais e geogárficas no desempenho da assistência prénatal de uma Região Metropolitana do Brasil. Ciên Saúde Colet. 2020. https://doi.org/10.1590/1413-81232020255.32852019.

9. Holowko N, Mishra G, Koupil I. Social inequality in excessive gestational weight gain. Int J Obes. 2013. https://doi.org/10.1038/ijo.2013.62.

10. Ivers LC, Cullen K. Food insecurity: special considerations for women. Am J Clin Nutr. 2011;94(Suppl 1):1740S-4S.

11. Sato APS, Fujimori E. Estado nutricional e ganho de peso de gestantes. Rev Latino-Am Enfermagem. 2012;20:3.

12. Food and agriculture organization of the united nations/Food security and nutrition around the world in 2017. In: The State of food security and nutrition in the world. Building resilience for peace and food security. 2017. http://www.fao.org/3/17695e/17695e.pdf. Accessed 15 Mar 2021.

13. Food and agriculture organization of the united nations/Livestock in balence. In: The State of food and agricultures. Livestock in the balance. 2009

14. Salles-costa R. Diagnóstico de Insegurança alimentar nos estudos populacionais: Suas implicações e limitações como indicador de SAN. In: Shneider O, editor. Segurança Alimentar e Nutricional. Tecendo a rede de saberes. Brasil: FAPERJ; 2012. p. 121-38.

15. Segall-Corrêa AM, Marin-León L, Melgar-Quiñonez H, Pérez-Escamilla R. Refinement of the Brazilian household food insecurity measurement scale: recommendation for a 14-item EBIA. Rev Nutr Campinas. 2014;27:241-51.

16. Food and agriculture organization of the united nations/Food security and nutrition around the world in 2020. In: The State of Food Security and Nutrition in the World 2020. Transforming food systems for affordable healthy diets. 2020. http://www.fao.org/3/ca9692en/online/ca9692en.html. Accessed 15 Mar 2021.

17. Instituto brasileiro de geografia e estatistica/Pesquisa de orçamentos familiares 2017-2018. Analise da ssegurança alimentar no Brasil. 2020. https://biblioteca. ibge.gov.br/visualizacao/livros/liv101749.pdf. Accessed 15 Mar 2021.

18. Lignani JB, Palmeira PA, Antunes MML, Salles-Costa R. Relationship between social indicators and food insecurity: a systematic review. Rev Bras Epidemiol. 2020. https://doi.org/10.1590/1980-549720200068.

19. Campos JM, Akutsu RCCA, Silva ICR, Oliveira KS, Monteiro R. Gênero, segurança alimentar e nutricional e vulnerabilidade: o Programa das Mulheres Mil em foco. Cien Saude Colet. 2020. https://doi.org/10.1590/141381232020254.22112018 .

20. Augusto ALP, Abreu Rodrigues AV, Domingos TB, Salles-Costa R. Household food insecurity associated with gestacional and neonatal outcomes: a systematic review. BMC Pregnancy Childbirth. 2020. https://doi.org/10.1186/ s12884-020-02917-9.

21. Secretaria do Estado de Saúde, Rio de Janeiro. Planejamento Regional 2012-2013-Meropolitana II. https://www.saude.rj.gov.br/comum/code/ MostrarArquivo.php?C=NjM1MQ\%2C\%2C. Accessed 15 Mar 2021.

22. Programa das nações unidas para o desenvolvimento/ Instituto de pesquisa econômica aplicada/ Fundação João Pinheiro. Atlas do Desenvolvimento Humano nas Regiões Metropolitanas Brasileiras - Indice de desencolvimento humano municipal. 2013. http://atlasbrasil.org.br/2013/pt/ consulta/. Accessed 15 Mar 2021.

23. Dale O, Salo M. The Helsinki declaration, research guidelines and regulations: present and future editorial aspects. Acta Anaesthesiol Scand. 1996;40:771-2. 
24. Institute of medicine (IOM): National Research Council. Weight Gain During Pregnancy: Reexamining the Guidelines. 2009.

25. Segall-Correa AM. Insegurança alimentar medida a partir da percepção das pessoas. Estudos avançados. 2007;21:143-54.

26. Perez-Escamilla R, Segall-Correa AM. Food insecurity measurement and indicators. Rev Nutr Campinas. 2008:21(Suppl 1):15-26.

27. Interlenghi GS, Reichenheim M, Segall-Correa AM, Pérez-Escamilla R, Moraes $\mathrm{CL}$, Salles-Costa R. Modeling optimal cutoffs for the Brazilian household food insecurity measurement scale in a nationwide representative sample. J Nutr. 2017;147:1356-65.

28. Marmitt LP, Gonçalves CV, Cesar JA. Healthy gestational weight gain prevalence and associated risk factors: a population-based study in the far South of Brazil. Rev Nutr Campinas. 2016;29:445-55.

29. Stulbach TE, Benicio MHD, Andreazza R, Kono S. Determinantes do ganho ponderal excessivo durante a gestação em serviço público de pré-natal de baixo risco. Rev Bras Epidemiol. 2007;10(1):99-108.

30. Krukowski R, Bursac Z, McGehee MA, West D. Exploring potential health disparities in excessive gestational weight gain. J Women's Health. 2013. https://doi.org/10.1089/jwh.2012.3998.

31. Liu J, Gallagher AE, Carta CM, Torres ME, Moran R, Wilcox S. Racial differences in gestational weight gain and pregnancy-related hypertension. 2014. https://doi.org/10.1016/j.annepidem.2014.02.009.

32. Instituto brasileiro de geografia e estatistica/Sintese de indicadores sociais/ Uma analise das condições de vida da população brasileira. 2020. https:// www.ibge.gov.br/estatisticas/multidominio/genero/9221-sintese-de-indica dores-sociais.html?t=publicacoes. Accessed 15 Mar 2021.

33. Brasil. Presidência da República. Lei n¹3152, 29 de julho de 2015/Decreto n 9.255, 29 de dezembro de 2017. 2017; http://www.planalto.gov.br/ccivil_ 03/_ato2015-2018/2017/decreto/d9255.htm\#textoimpressao. Accessed 2 Apr 2021.

34. Instituto de pesquisa e economia aplicada/ Taxa de cambio commercial para venda: real/dolar americano—-media. http://www.ipeadata.gov.br/ ExibeSerie.aspx?serid=3192. Accessed 2 Apr 2021.

35. Instituto brasileiro de geografia e estatistica/Pesquisa de amostras por domicilios 2013/Síntese de indicadores 2013. 2015. https://biblioteca.ibge. gov.br/visualizacao/livros/liv94414.pdf. Accessed 14 Mar 2021.

36. Deputy NP, Sharma AJ, Kim SY, Hinkle SN. Prevalence and characteristics associated with gestational weight gain adequacy. 2015. https://doi.org/10.1 097/AOG.0000000000000739.

37. Homer D, Lemeshow S. Applied logistic regression. New York: Wiley; 2000.

38. Abreu MNS, Siqueira AL, Caiaffa WT. Regressão logística ordinal em estudos epidemiológicos. Rev de Saúde Pública. 2009;43:18.

39. StataCorp/Stata Statistical Software: Release 16. College Station, TX: StataCorp LLC; 2019.

40. Jonhson J, Clifton RG, Roberts JM, Myatt L, Hauth JC, Spong CY, et al. Pregnancy outcomes with weight gain above or below the 2009 Institute of Medicine Guidelines. Obstet Gynecol. 2013;121:969-75.

41. Campos CAS, Malta MB, Neves PAR, Lourenço BH, Castro M, Cardoso MA. Gestational weight gain, nutritional status and blood pressure in pregnant women. Rev Saude Publica. 2019. https://doi.org/10.11606/S1518-8787201 9053000880 .

42. Fraga ACSA, Filha MMT. Factors associated with gestational weight gain in pregnant women in Rio de Janeiro, Brazil, 2008. Card Saude Publica. 2014 https://doi.org/10.1590/0102-311X00085313.

43. Brasil. Ministério da Saúde. Secretarria de atenção primária. Sistema de vigilância alimentar e nutricional, 2019. http://sisaps.saude.gov.br/sisvan/rela toriopublico/estadonutricional. Accessed 8 Jan 2020.

44. Oliveira ACM, Tavares MCM, Bezerra AR. Insegurança alimentar em gestantes da rede pública de saúde de uma capital do nordeste brasileiro. Cien Saúde Colet. 2017;22:519-26.

45. Marano D, Gama SGN, Pereira APE, Junior PRBS. Adequação do ganho ponderal de gestantes em dois municípios do estado do Rio de Janiero (RJ), Brasil, 2008. Rev Bras Ginecol Obstet. 2012;34:8.

46. Análise da Segurança alimentar. In: Pesquisa de Orçamentos Familiares 2017-2018. Instituto Brasileiro de Geografia e Estatisticas; 2020. Accessed 18 Sep 2020

47. Food Security and Nutrition Around the World in 2020. In: The State of food security and nutrition in the world. Transforming food systems for affordable healthy diets. Food and Agriculture Organization of the United Nations. 2020. Accessed 26 Aug 2020.
48. Demétrio F, Teles CAS, Santos DB, Pereira M. Food insecurity in pregnant women is associated with social determinants and nutritional outcomes: a systematic review and meta-analysis. Ciên Saúde Colet. 2020. https://doi. org/10.1590/1413-81232020257.24202018.

49. Thomas M, Vieten C, Adler N, Ammondson I, Coleman K, Epel E, et al. Potential for a stress-reduction intervention to promote healthy gestational weight gain: focus groups with low income pregnant women. Womens Health Issues. 2014. https://doi.org/10.1016/j.whi.2014.02.004.

50. Laraia B, Siega-Riz AM, Gundersen G. Household food insecurity is associated with self-reported pre gravid weight status, gestational weight gain and pregnancy complications. J Am Diet Assoc. 2010;110:692-701.

51. Min J, Li Z, Liu X, Wang Y. The association between early menarche and offspring's obesity risk in early childhood was modified by gestational weigth gain. Obesity. 2014;22:19-23.

52. Mc Clure CK, Catov JM, Ness R, Bodnar LM. Associations between gestational weight gain and $\mathrm{BMl}$, abdominal adiposity, and traditional measures of cardiometabolic risk in mothers 8y postpartum. Am J Clin Nutr. 2013;98:1218-25.

53. Brandão T, Silva KS, Sally EFO, Dias MA, Silva CVC, Fonseca VM. Características epidemiológicas e nutricionais de gestantes vivendo com o HIV. Rev Bras Ginecol Obstet. 2011;33:188-95.

54. Al Mamun A, Mannan M, O'Callaghan MJ, Williams GM, Najman JM, Callaway LK. Association between gestational weight gain and pospartum diabetes: evidence from a community based large cohort study. Plos One. 2013. https://doi.org/10.1371/journal.pone.0075679.

55. Bjermo $\mathrm{H}$, Lind S, Rasmussen F. The educational gradient of obesity increases among Swedish pregnant women: a register-based study. BMC Public Health. 2015. https://doi.org/10.1186/s12889-015-1624-6.

56. Sridher SB, Darbinian J, Ehrlich SF, Markman MA, Gunderson EP, Ferrara A, et al. Maternal gestational weight gain and offspring risk for childhood overweight or obesity. Am J Obstet Gynecol. 2014. https://doi.org/10.1016/ j.ajog.2014.02.030

57. Flor LS, Laguardia J, Campos MR. Mobilidade social intergeracional e saúde no Brasil: uma análise do survey "Pesquisa dimensões sociais das desigualdades (PDSD)", 2008. Ciên Saúde Colet. 2014;19:1869-80.

58. Marques BL, Tomasi YT, Saraiva SS, Boing AF, Geremias DS. Orientações às gestantes no pré-natal: a importância do cuidado compartilhado na atenção primária em saúde. Esc Anna Nery. 2021. https://doi.org/10.1590/21 77-9465-ean-2020-0098.

59. Vanstone M, Sadik M, Blyderveen SV, Biringer A, Sword W, Schmidt L, et al. Competing priorities: a qualitative study of how women make and enact decisions about weight gain in pregnancy. BMC Pregnancy Childbirth. 2020. https://doi.org/10.1186/s12884-020-03210-5.

60. Huber LRB. Validity of self-reported height and weight in women of reproductive age. Matern Child Health J. 2006;11:137-44

61. Feriani LO, Coutinho ESF, Silva DA, Faria CP, Molina MCB, Bensenor IJM, et al. Subestimativa de obesidade e sobrepeso a partir de medidas autorrelatadas na população geral: prevalência e proposta de modelos para correção. Cad Saúde Pública. 2019. https://doi.org/10.1590/0102-311 X00065618.

62. Conde WL, Oliveira DR, Borges CA, Baraldi LG. Consistência entre medidas antropométricas em inquéritos nacionais. Rev Saúde Pública. 2013;47:69-76.

63. Muktabhant B, Lawrie TA, Lumbiganon P, Laopaiboon M. Diet or exercise, or both, for preventing excessive weight gain in pregnancy. Cochrane Database Syst Rev. 2015. https://doi.org/10.1002/14651858.CD007145.pub3.

\section{Publisher's Note}

Springer Nature remains neutral with regard to jurisdictional claims in published maps and institutional affiliations. 